\title{
NIEZNANA IKONA Z MIELNIKA. PRZYCZYNEK DO DZIEJÓW IKON NA PODLASIU
}

Dzieje lokalnych ikon, jednego z najbardziej oryginalnych składników dziedzictwa kulturowego Podlasia, nie zostały dotychczas zbadane. Nie wiemy, kiedy się pojawiły i skąd się wywodziły, nie wiemy też, jak wyglądały podlaskie ikony. Najstarsze wzmianki o nich odnoszą się do początków drugiej połowy XIII w.: tzw. Latopis Ipatiewski pod 1260 r. wymienia cerkiew Bogurodzicy w Mielniku, w której modlił się do Boga, do Spasa Izbawnika, Wasilko, brat księcia Daniela ${ }^{1}$. Interesujący dla nas fragment brzmi tak: „и помолився Бо[г]у с[вя]т[о]му Сп[а]су. избавнику яже есть икона яже есть в городе мелнице во ц[е]ркви с[вя]тое Б[огороди]це и ныне стоить в велице ч[е]сти" 2 .

Zatem w 1260 r. Wasilko przybył do Mielnika33, by w cerkwi Bogurodzicy pomodlić się przed ikoną cieszącą się wielką czcią. Wielu historyków

1 Daniel Halicki, [w:] Encyklopedia Katolicka, red. R. Łukaszyk, L. Bieńkowski, F. Gryglewicz, t. III, Lublin 1985, szp. 1006-1007 [L. Bieńkowski]; zob.: Н. Карамзин, История государства Российскаго, t. IV, С. Петербург 1819, с. 20-74; Городския поселения в Российской империи, t. II, С. Петербург 1861, s. 85-87.

2 Полное собрание русских летописей, Изданное по Высочайшему повелению Императорскою Археографическою Коммиссиею, t. II, Санкт Петербург 1908, s. 847; według Ignacego Daniłowicza, cytującego ten fragment w autorskiej transliteracji, brzmi on tak: „R. 1260: I jecha Wasilko za brata i prowodi jego do Brestja i posła s nim ljudi swoja, i pomolisja Bohu, jaże jest' ikona, jaże jest' w hordje Mielnici w cerkwi Sw. Bohorodicy i objeszczasja Daniło ukrasiti ju". I. Daniłowicz, Skarbiec diplomatów papieskich, Wilno 1860, s. 103; krytyczne opracowanie zbioru: F. Zieliński, Zbiór zupełny ruskich latopisarzy wydany z najwyższego rozkazu przez Kommissyę archeograficzna, „Biblioteka Warszawska, Pismo poświęcone naukom, sztukom i przemysłowi" [1845], t. IV, s. 1-43.

3 Mielnik, [w:] SGKP, t. VI, Warszawa 1885, s. 346 [J. Krzywicki]; Городския поселения, t. II, s. 96; Епископ Иосиф [Соколов], Гродненский православно-иерковньий календарь или православное обозрениие в Брестско-гродненской земле в коние XIX в., t. I, Воронеж 1899, s. 238. 
odczytuje ów fragment jako potwierdzenie obecności w cerkwi Bogurodzicy w Mielniku ikony określanej mianem obrazu Spasa Izbawnika ${ }^{4}$. Mimo że $\mathrm{w}$ popularnych słownikach ikonograficznych taki temat istotnie nie jest notowany, w cytowanym źródle określenie to się pojawiło.

Historycy podjęli próby jej zidentyfikowania i weryfikacji tautologicznego określenia ikony, wywodzącego się być może z pobożności ludowej.

Zdaniem Antoniego Mironowicza ciesząca się szczególnym kultem ikona Spasa Izbawnika w czasie tatarskiego najazdu została wywieziona z cerkwi w bezpieczne miejsce i nie wróciła już do Mielnika ${ }^{5}$, ponieważ książęta litewscy nie byli zainteresowani rozwojem kultu ${ }^{6}$. Temu twierdzeniu przeczy praktyka oddawania czci słynącym łaskami obrazom niezależnie od konfesji. Jest też faktem, że obrazy bizantyjskiej proweniencji były otoczone szczególnym zainteresowaniem i kultem, bardzo wiele takich wizerunków znajdowało się w kościołach katolickich również na Podlasiu 7 . Warto też pamiętać, że w średniowieczu wizerunki nie różniły się od siebie pod względem formalnym, nie było zatem rozróżnień między ikoną i obrazem.

Ksiądz Grzegorz Sosna, opierając się na relacji ks. Eugeniusza Niesteruka, badającego akta parafialne z przełomu XVIII i XIX w., twierdzi, że w Mielniku istniała ikona Matki Boskiej Orantki: "Jesienią 1777 roku został wyłowiony obraz Matki Bożej Pokrowskiej z rzeki Bug i pod przewodnictwem ówczesnego proboszcza cerkwi Świętopreczystieńskiej ks. Jakuba Bielawskiego, przy licznym udziale parafian, został przeniesiony do cerkwi parafialnej. Przy obrazie płynącym po wodzie znajdowało się naczynie z farbą i pędzel. Ikona wykonana była na desce o wymiarach 117 x $67 \mathrm{~cm}$

4 G. Sosna, Rys historyczny parafii prawosławnej Siemiatycze na tle historii miasta, „Wiadomości Polskiego Autokefalicznego Kościoła Prawosławnego" (dalej: Wiadomości PAKP) [1983], nr 3, s. 61; Narodowy Instytut Dziedzictwa (dalej: NID), Warszawa, Oddział Terenowy Białystok; M. Giedz, Grabarka - cerkiew i klasztor pw. śs. Marty i Marii, Studium historyczno-architektoniczne, [mps], Białystok 1985; G. Sosna, A. Troc-Sosna, Święte miejsca i cudowne ikony, Prawosławne sanktuaria na Białostocczyźnie, Białystok 2006, s. 40; A. Bobryk, Święta Góra Grabarka jako ośrodek pielgrzymkowy, „Białoruskie Zeszyty Historyczne” (dalej: BZH) [2006], nr 26, s. 109 i n.; A. Mironowicz, Grabarka, „Białostocczyzna” [1986], nr 2, s. 17; tenże, Sanktuarium prawosławne na Św. Górze Grabarce, BZH [2007], nr 27, s. 168-174; tenże, Z dziejów prawosławia na Białostocczyźnie, BZH [1998], nr 10, s. 13; D. Michaluk, Rezydencja hospodarska w Mielniku w XIV-XVI w., „Białostocczyzna” [1991], nr 3 (23), s. 1; taż, Ziemia mielnicka województwa podlaskiego w XVI-XVII w., Toruń 2002, s. 129.

5 A. Mironowicz, Grabarka, „Białostocczyzna” [1986], nr 2, s. 17.

6 Tamże, s. 18; tenże, Sanktuarium prawosławne..., s. 168 i n.

7 M.P. Kruk, Ikony-obrazy w świątyniach rzymsko-katolickich dawnej Rzeczypospolitej, Kraków 2011, passim. 
i stanowiła dzieło niedokończone przez malarza" ${ }^{8}$. Zachowany do dziś wizerunek Matki Boskiej Orantki, namalowany (właściwie jest to tylko zarys postaci) techniką temperową na desce o takichże wymiarach, jest datowany na przełom XVIII i XIX w. ${ }^{9}$, zapewne o nim opowiada cytowane źródło.

Józef Maroszek, opierając się na stwierdzeniu, iż w literaturze przedmiotu nie pojawia się określenie Spas Izbawnik, zakwestionował istnienie takiej ikony, wysuwając przypuszczenie, że w tekście źródłowym jest mowa o ikonie Matki Boskiej ${ }^{10}$. Autor przedstawił tezę, iż przechowywany do $1945 \mathrm{r}$. obraz z lwowskiego kościoła dominikanów, dziś znajdujący się w kościele św. Mikołaja w Gdańsku, jest tożsamy z ikoną opisaną w latopisie halicko-wołyńskim, przed którą modlił się Wasilko, brat księcia Daniela. Tezę tę wyklucza datowanie lwowskiej ikony na drugą połowę XIV w. ${ }^{11}$

Trzeba się zgodzić z Józefem Maroszkiem, iż teza o modlitwie Wasilka przed ikoną Spasa Izbawnika jest nadinterpretacją, temat ikony zaś pozostaje problemem niewyjaśnionym. Pewne światło rzuca na ten problem XIX-wieczna literatura rosyjska. Fiodor Pokrowski, który widział cerkiew mielnicką w drugiej połowie stulecia, potwierdził obecność ikony maryjnej: „В олтаре мельницкой церкви есть явлена чудотворная икона Богоматери, которая по преданию явилась в лодке на реке". Według niepotwierdzonego przekazu zapisanego przez Fiodora Pokrowskiego w łódce znaleziono także „палитры, кисти и красок двенадцати цветов" ${ }^{12}$. Zdaniem mielnickiego duchownego, odnotował autor, w ołtarzu znajdowała się ta sama ikona, przy której w 1260 r. modlił się książę Daniel ${ }^{13}$.

Podobną opinię przekazał biskup Josif, dodając, iż „явленная чудотворная икона Богородицы давного письма на дереве [...] в медной озолоченной ризе и венцах", „По преданию приплывшая на лодке по

8 G. Sosna, A. Troc-Sosna, dz. cyt., s. 254-255.

9 Archiwum Wojewódzkiego Urzędu Ochrony Zabytków, Białystok, J. Hościłowicz, Karta ewidencyjna zabytku, 1977, nr 2487; Katalog zabytków sztuki w Polsce (dalej: KZSP), Województwo białostockie, t. XII, z. 1, Siemiatycze, Drohiczyn i okolice, red. i oprac. aut. M. Kalamajska-Saeed, Warszawa 1996, s. 37.

10 J. Maroszek, Lwowski wizerunek Matki Boskiej Zwycięskiej - podlaskie wotum Daniela Romanowicza?, [w:] Eikon staroobrzędowy, s. 241.

11 B. Dąb-Kalinowska, Ikony i obrazy, Warszawa 2000, s. 142.

12 Ф. Покровский, Археологическая карта Гродненской губернии, Вильна 1895, s. 107.

13 Tamże; tę wiadomość powtórzyli inni autorzy, por. G. Sosna, A. Troc-Sosna, dz. cyt., s. 255; J. Charkiewicz, Tobq raduje się całe stworzenie, Ikony Bogarodzicy w prawosławiu [wyd. II poprawione i uzupełnione], Warszawa 2009, s. 155-156; zdaniem autorów cytowany opis może dotyczyć ikony Matki Boskiej Orantki, istniejącej do dziś w cerkwi Narodzenia NMP w Mielniku. 
реке Западному Бугу. Полагают, что это та святая икона, перед которую в 1260 году, по Ипатиевской летописи, усердно молился князь Аанил Галицкий, как состоявшею в велицей чести"14. Zdaniem biskupa Josifa ikona mierzyła 1 arszyn i 2 werszki wysokości, czyli około $80 \mathrm{~cm}$, szerokość obrazu nie została podana ${ }^{15}$.

Przed czyim wizerunkiem modlił się brat księcia Daniela? By podjąć próbę wyjaśnienia tej kwestii, przypomnijmy analogiczny problem interpretacyjny: Wasilij Pucko przytoczył fragment Latopisu Radziwiłłowskiego (k. 138) zestawiony z ilustracją. Miniatura ilustruje chwilę okrutnego oślepienia kniazia Wasilka Rościsławowicza i jego modlitwę przed ikoną Pantokratora w cerkwi Archanioła Michała w klasztorze Wydubickim w Kijowie, natomiast tekst informuje, iż kniaź „иде поклониться святому Михаилу в монастырь", со można rozumieć jako modlitwę przed ikoną Archanioła Michała ${ }^{16}$. Jednakże miniatura rozwiewa wszelkie wątpliwości: Wasilko modlił się w klasztornej cerkwi św. Michała przy ikonie Chrystusa Pantokratora.

Jak się zatem wydaje, interpretacje XIX-wiecznych autorów rosyjskich w odniesieniu do ikony z Mielnika nie pozostawiają żadnych wątpliwości, interesująca nas ikona przedstawiała wizerunek Matki Boskiej.

Tak więc o ikonie, którą w mielnickiej cerkwi widzieli Fiodor Pokrowski i biskup Josif, wiemy bardzo niewiele: zapewne została namalowana linearnie, stąd określenie "„авного письма", na desce o wysokości około $80 \mathrm{~cm}$, przykrytej złoconą metalową ryzą zdobioną nakładanymi aureolami. Różnica w wysokości ikony, podana przez biskupa Josifa i ks. Eugeniusza Niesteruka, świadczy o tym, że mowa tu o różnych ikonach. Nie wiemy, kiedy powstała ikona, którą wzmiankowali cytowani autorzy, lecz jest bardzo wątpliwe, by w końcu XIX w. w prowincjonalnej mielnickiej cerkwi zachował się XIII-wieczny wizerunek. Najpewniej istotnie w tym czasie w świątyni znajdowała się stara ikona z przedstawieniem Matki Boskiej, którą - na podstawie ówczesnej wiedzy - uznawano za tożsamą z obrazem notowanym w Latopisie. Być może obraz opisany przez Fiodora Pokrowskiego i biskupa Josifa pojawił się w Mielniku w czasie rebizantynizacji podlaskich cerkwi po zniesieniu unii brzeskiej?

14 Епископ Иосиф [Соколов], Гродненский православно-иерковный календарь, s. 238.

15 Jeden arszyn to $71 \mathrm{~cm}$, jeden werszek zaś - około 4,45 cm; D. Fenna, Jednostki miar, Leksykon, Warszawa 2002, s. 18.

16 В. Пуцко, Произведения искусства - реликвии древнего Киева, „Russia Mediaevalis”, [München 1987], t. VI/1, s. 142. 
Zapewne nigdy się nie dowiemy, jaki wizerunek należał do świętości mielnickiej cerkwi w XIII w. Według wszelkiego prawdopodobieństwa była to ikona z przedstawieniem Matki Boskiej z Dzieciątkiem, choć o postaci Chrystusa - Emanuela nie wspominają autorzy rosyjscy.

Opromienione sławą obrazów czyniących cuda wizerunki Matki Boskiej na obszarze Rzeczypospolitej tworzą długą listę i należą do najważniejszych obiektów chrześcijaństwa ${ }^{17}$. Dogmatyczny charakter czci oddawanej ikonom został ustalony po okresie ikonoklazmu ${ }^{18}$. Nauka Soboru Nicejskiego z 787 r. (do nich odwołał się później Sobór Trydencki) stała się teologiczną podstawą malarstwa ikonowego: „Nauczono chrześcijan przedstawiać obraz Chrystusa w zgodzie z Jego widzialną naturą, a nie z tą, która sprawia, iż nie jest widzialny, ta druga bowiem nie daje się opisać [...]. Skoro przedstawia się Chrystusa zgodnie z Jego ludzką naturą, jest oczywiste, że chrześcijanie jak to wykazała Prawda - uznają zgodność obrazu widzialnego z Archetypem tylko co do Imienia, lecz nie co do natury"19. Ikony słynące cudami są więc tymi, w których zawiera się istota obrazu, pełnią też funkcje palladium, chronią miejsce, w którym się znajdują.

Pierwszym autorem wizerunków Matki Boskiej z Dzieciątkiem miał być św. Łukasz Ewangelista ${ }^{20}$. W tzw. liście patriarchów Aleksandrii, Antiochii i Jerozolimy do cesarza Teofila z 836 r. autorzy wymienili dwanaście ikon, zgodnie $z$ tradycją pochodzących z czasów Chrystusa, wśród nich był obraz pobłogosławiony przez Matkę Boską. Ta opowieść przetrwała do późnego średniowiecza w Kościołach obu tradycji ${ }^{21}$.

17 A. Witkowska, Maryjne loca sacra na ziemiach dawnej Rzeczypospolitej w początkach XIX w., [w:] Przestrzeń i sacrum, Geografia kultury religijnej w Polsce $i$ jej przemiany w okresie od XVII do XX w. na przykładzie ośrodków kultu i migracji pielgrzymkowych, red. A. Jackowski, Kraków 1995, s. 105-121.

18 The Seventh General Council, The Second of Nicea, Held A. D. 787 in which the worship of Images was established, London 1850, passim; T. Trajdos, Kult wizerunków maryjnych na ziemiach ruskich Korony i Litwy drugiej połowy XIV i pierwszej połowy XV w. w społecznościach katolickiej i prawosławnej, „Studia Claromontana” [1984], t. V, s. 128.

19 Postanowienia Siódmego (Nicejskiego) Soboru ekumenicznego z 787 r., [w:] Myśliciele, kronikarze i artyści o sztuce od starożytności do 1500 r., red. J. Białostocki, Warszawa 1988, s. 214.

20 E. von Dobschütz, Christusbilder, Texte und Untersuchungen zur altchristlichen Legende, t. II, Leipzig 1899; Н.П. Кондаков, Иконография Богоматери, t. I, II, Петрограх 1915; С. Angelidi, T. Papamastorakis, The Veneration of the Virgin Hodegetria and the Hodegon Monastery, [w:] Mother of God, Representations of the Virgin in Byzantine Art, red. M. Vassilaki, Athens 2000, s. 373-387; А. Аидов, Иеротопия, Пространство иконь и образы - парадигмь в византийской культуре, Москва 2009.

21 R. Maniura, Pilgrimage to Images in 15th c., The Origins of the Cult of Our Lady of Częstochowa, Wiltshire 2004, s. 60. 
W tekście poświęconym roli ikon w Cerkwi prawosławnej Atanazy Kalnofojski ${ }^{22}$, przywołując tezy św. Jana z Damaszku, stwierdził: „Obraz iest podobieństwo, przykład i konterfektowanie, które tego w sobie, którego iest obraz, wyraża [...]. Obraz iest podobieństwo tak swoy exemplarz wyrażające, izby przecie od niego czym różniło [...]. Obraz dla tego bywa, że człowiek rzeczy tych, które widziane bydź nie mogą, dosięgnąć wiadomości nie może, iż iest ciałem obciążony, ani wiedzieć rzeczy daleko od siebie odłączonych [...]. Dlatego tedy obrazy wynalezione, aby nam do rzeczy zakrytych wiadomości iako niejakimś przewodnikami były" ${ }^{23}$. Dalej uczony zakonnik podkreślił, że „obrazowa cześć przechodzi na samy exemplarz, do którego ma relatia to malowanie [...]. Gdy iednego świętego obrazy takąż łaskę przyięły, iako sam święty, czemu wszystkie nie są cudotworze? Odpowiadam: lubo to Pan Bóg przez ten obraz a nie ów cuda czyni [...] posięgnąć tego jednak może wiary wielka siła, y to sprawić, że tegoż y iednego świętego po wielu miejscach conterfety (sic!) cudowne bydź mogą"24.

Tak więc kult Matki Boskiej jako najważniejszej pośredniczki między Bogiem i wiernymi, Królową Niebios, Mater Misericordiae, Mater Dolorosa, Pocieszycielką i Opiekunką od wczesnego okresu chrześcijaństwa odgrywał rolę nadzwyczaj ważną ${ }^{25}$. Słynące łaskami ikony były otoczone czcią w cesarstwie bizantyjskim, tam też powstało wiele archetypów, ikon, które stały się wzorcami dla wielu innych powtórzeń ${ }^{26}$. Zapewne stamtąd wywodził się archetyp ikony z Mielnika.

Czy w mielnickiej cerkwi istniała maryjna ikona otoczona kultem? Może pamięć o średniowiecznym wizerunku przetrwała?

22 Atanazy Kalnofojski (daty życia nieznane) - prawosławny zakonnik kijowskiej Ławry Pieczerskiej, autor książki Teratourgema lubo cuda, które były tak w samym świętym cudotwornym monastyru Pieczarskim Kiiowskim, Kijów 1638; I. Stebelski, Dwa wielkie światta na horyzoncie połockim z cieniów zakonnych powstające, t. 1, Lwów 1866, s. XXVIII; L. Charipova, Latin books and the Eastern Orthodox elite in Kiev 1632-1780, Manchester 2006, s. 61, 166.

23 Извлечение из Тератоургмь Афанасия Кальнофойского изданной в 1638 г., [w:] Архив юуго-запалной России, t. VIII, cz. I, Памтники литературной полемики православных юужно-руссов з латино-униатами в Юуго-западной Руси за XVI и XVII в., Киев 1914, s. 495 i n.

24 Tamże, s. 497 i n.

25 Por.: A. Gąsior, Die Gottesmutter, Marias Stellung in den religiösen und politischen Kultur Polens, [w:] Die Renaissance der Nationalpatrone, Erinnerungskulturen in Ostmitteleuropa in 20/21 Jahrhundert, red. S. Samerski, Leipzig 2007, s. 77.

26 I. Sirota, Ikonographie der Gottesmutter in der Russischen Orthodoxen Kirche, Versuch einer Systematisierung, Würzburg 1992, s. 16 i n.; zob.: I. Bentchev, Handbuch der Gottesmutterikonen Rußlands, Gnadenbilder - Legenden - Darstellungen, Bonn-Bad Godesberg 1985, s. 17 i n.; Чудотворная икона в Византии и древней Руси, red. А. Аидов, Москва 1996, passim. 
W późniejszych wiekach w Mielniku, stolicy dekanatu położonego w diecezji brzeskiej27, funkcjonowały dwie unickie cerkwie: Narodzenia NMP i Zmartwychwstania Pańskiego ${ }^{28}$. Obie były kilkakrotnie wizytowane, dzięki czemu znamy opisy ich wyposażenia.

Cerkiew Narodzenia NMP istniała już w 1551 r. ${ }^{29}$ i zapewne była jedną z najstarszych świątyń na Podlasiu. Nie znamy daty jej powstania, lecz wydaje się mało prawdopodobne, by przetrwała od średniowiecza do czasów nowożytnych. Jej wyposażenie zostało opisane w 1727 r.: „Deisus z Prorokami i Apostołami nieźle accomodowany. Niżey obrazów wielkich w rząd stoiących siedm. Namiesnych Obrazów trzy z prostemi Ołtarzykami Carskie Drzwi snicerskiey roboty oprawne ze wszytkim porządne [...]. Ołtarzy niby bokowych dwa [...] ieden z obrazem S. Jerzego, a drugi z pięcią Obrazami nieporządnie disponowanemi - oba nude sprosta bez żadnych Akkomodacyi" ${ }^{30}$.

W wizytacji z 1774 r. ks. Symeon Markiewicz zapisał: „Ołtarz wielki [...] z obrazem Narodzenia Maryi Panny. Namiesnych ołtarzyków snycerskiey roboty ieden $z$ obrazem Matki Boskiey pomalowany i srebrzony [...], drugi z obrazem Spasitiela na tablicy ponad któremi idzie Deisus z Dwunastą Apostołami i Archijereyem na Majestacie, Carskie wrata snycersko rznięte pozłocone. Pobocznych ołtarzów stolarskiey roboty pomalowanych ieden z obrazem Stego Nikołaja drugi Protekcji Maryi Panny [...]. Innych obrazów na Płotnie y tablicach rózney miary $5^{\prime \prime} 31$.

Opis z wizytacji z 1781 r. przedstawia się identycznie i zapewne został powtórzony za starszym źródłem ${ }^{32}$.

W 1797 r. cerkiew była już stara, w jej wnętrzu „,...] ołtarz wielki snicerskiey roboty [...] z obrazem zesłania Ducha Świętego i Taflą małą Narodzenia Pana Jezusa, w górze zaś Narodzenia Panny Maryi [...]. Item Ikonostas nad Carskiemi Drzwiami snycerskiey roboty malowanemi i złoconemi, na których Passia Pana Jezusa z Archiiereyem Dwunastą Apostołami i Prorokami koło których drzwi. Ołtarzyków dwa snicerskich [...], ieden z obrazem Spasy-

27 W. Kołbuk, Kościoły Wschodnie w Rzeczypospolitej około 1772 r., Lublin 1998, s. 317.

28 Cerkiew istniała w początkach XVII w.; Акть издаваемые виленскою археографическою коммиссиею, t. XXXIII, Вильна 1908, s. LXIX.

29 Акты издаваемье, t. XXXIII, s. LXIX; KZSP, Województwo białostockie, t. XII, z. 1, s. 36.

30 Archiwum Państwowe, Lublin (dalej: APL), Chełmski Konsystorz Greckokatolicki (dalej: CHKGK), Protokoły wizytacyjne i wizytacja generalna cerkwi w diecezji chełmskiej, bełskiej i brzeskiej, sygn. 101, k. 338-339.

31 APL, CHKGK, Wizyty cerkwi diecezji brzeskiej dekanatu mielnickiego przez Księdza Symeona Markiewicza w 1774 r. odprawione, sygn. 121, k. 42.

32 APL, CHKGK, Wizyty cerkwi diecezji brzeskiej dekanatu mielnickiego [1781-1782] odprawione, sygn. 130, k. 19. 
tela Drugi Matki Boskiey [...]. Item ołtarzyków snicerskich [...] malowanych z obrazami, ieden Protekcyi Matki Boskiey, drugi So Mikołaia [...]. Obrazow różnych na płótnie i tablicach malowanych sześć" 33 .

Jak wynika z wizytacji z 1804 r., wyposażenie świątyni uległo zmianie: „Ołtarzow w tey cerkwi [...] iest pięć. Z tych wielki ołtarz z Deisusem i Carskiemi Drzwiami [...]. Na mensie [nad cyborium] okręca się na walcu z jedney strony obraz N. Panny Niepokalanego Poczęcia z drugiey figura P. Jezusa [...]. Na obu stronach Drzwi Carskich ołtarze takiejże roboty wyzłacane jak Wielki Ołtarz, z których w jednym obraz Zbawiciela P. w drugim zaś Nays. Panny z zasuwką Matki Bolesney [...]. Po prawey stronie S. Mikołaia po lewey zaś protekcji Nays. Panny malowane [...]. Obrazów do ścian przybitych dużych Dwa y małych Dwa" 34 .

$\mathrm{W}$ tej cerkwi w $1774 \mathrm{r}$. w jednym z ołtarzy namiestnych znajdował się obraz "Matki Boskiey pomalowany i srebrzony na Obrazie Sukienka Papierowa posrebrzana częścią złocona", lecz nie mamy żadnego potwierdzenia jego niezwykłych właściwości. Zapewne ten sam został wymieniony w wizycie z 1804 r. jako umieszczony w bocznym ołtarzu przy królewskich drzwiach ikonostasu.

Cerkiew Zmartwychwstania Pańskiego (Woskresieńska) była skromniej wyposażona: „Ołtarz Wielki Snicerskiey roboty po bokach z dwiema Fortami ieszcze niepomalowany z Obrazem Zmartwychwstania [...]. Ołtarzow Pobocznych dwa ieden [...] z obrazem So Antoniego. Drugi stary, w tych ołtarzach obrazy na Płotnie malowane No 3. Innych obrazów różney miary No 7"35.

Według wizytacji z 1797 r. w świątyni znajdował się „Ołtarz wielki snicerskiey roboty [...] z obrazem Zmartwychwstania Pańskiego [...]. Ołtarzyków pobocznych snycerskich dwa, ieden [...] z Obrazem Matki Boskiey piastuiącey Pana Jezusa [...] na wierzchu obraz Trojcy Świętey, drugi niemalowany $\mathrm{z}$ obrazem So Jozefa [...]. Item obrazow na Tabulaturach po ścianach starych siedm" 36 .

33 Litewskie Państwowe Archiwum Historyczne (Lietuvos valstybès istorijos archyvas) (dalej: LVIA), Wilno, Zbiór duchownego konsystorza litewskich unitów, sygn. F. 634-I-55, Akta wizytacji dekanatu bielskiego, drohiczyńskiego, mielnickiego, k. 59.

34 LVIA, Wilno, Zbiór duchownego konsystorza litewskich unitów, sygn. F. 634-I-59, Akta wizyty pełnej dekanatu drohiczyńskiego, s. 70-71.

35 APL, CHKGK, Wizyty cerkwi diecezji brzeskiej dekanatu mielnickiego przez Ks. Symeona Markiewicza w 1774 r. odprawione, sygn. 121, k. 7.

36 LVIA, Wilno, Zbiór duchownego konsystorza litewskich unitów, sygn. F. 634-I-59, Akta wizyty pełnej dekanatu drohiczyńskiego, k. 61: „Cerkiew drewniana, nadwątlona na węgłach, gątami kryta kopułą wporzrodku z krzyżem żelaznym sufit i podłogę tarciczną". 
Z wizytacji z 1804 r. wyposażenie cerkwi przedstawiało się skromniej: „Ołtarzów stolarskiey roboty trzy [...]. Ołtarz wielki [w którym] obraz w szufladzie Nysw. Panny na drzewie malowany zasuwaiący się obrazem [...] Zmartwychwstania Pańskiego, a ten zasuwa się obrazem Soboru N. M. P. także na płótnie malowany. Ołtarz z prawey strony [...] z obrazem So Mikołaja zasuwający się obrazem Stej Barbary. Z lewey strony ołtarz trzeci [...] z obrazem So Jozafata na płótnie malowanym" 37 .

Tak więc w żadnym protokole powizytacyjnym nie znalazło się bezpośrednie potwierdzenie niezwykłych właściwości jakiegokolwiek obrazu. Jaką zatem ikonę widzieli XIX-wieczni autorzy rosyjscy? Być może zaczerpnięte z Latopisu informacje o ikonie, przed którą się modlił Wasilko, i ustny przekaz o obrazie, który przypłynął rzeką Bug, zostały połączone w jedną opowieść?

Jeśli mielnicka ikona istotnie przedstawiała Matkę Boską z Dzieciątkiem, jaki wariant prezentowała?

Bazylianin Ignacy Stebelski w jednym ze swych fundamentalnych dzieł stwierdził, iż w czasach św. Eufrozyny Połockiej ${ }^{38}$, patronki Białorusi, sławne były trzy obrazy Hodegetrii, przypisywane św. Łukaszowi: jeden z nich był przechowywany w Efezie, drugi w Konstantynopolu, trzeci zaś w Jerozolimie ${ }^{39}$. Pobożna św. Eufrozyna „pomodliwszy się więc do Boga ze łzami względem otrzymania tego, czego żądała, wyprawiła sługę monastyra swego do Carogrodu do prawowiernego cesarza Manuela (Komnena) i do patriarchy Łukasza (Chrysoberga) z podarunkami i prośbami wielkimi, upraszając o jeden z tych obrazów najczystszej panny, a mianowicie o ten, który był

37 Tamże, s. 65-71.

38 Eufrozyna Połocka (ok. 1104-1173 lub 1167) - mniszka, igumenia, jedna z najbardziej wykształconych kobiet tego czasu, założycielka dwóch klasztorów w Połocku. Była córką połockiego księcia Jerzego Wsiesławowicza, niechętna małżeństwu opuściła dom rodzinny i za zgodą biskupa zamieszkała w celi przy katedrze w Połocku, prowadząc życie kontemplacyjne i działalność charytatywną. W latach 1140-1160 założyła klasztor żeński i męski, zbudowała cerkiew Zbawiciela i sprowadziła doń z Konstantynopola ikonę Matki Bożej. Ostatnie lata życia spędziła w Ziemi Świętej, gdzie umarła; Православная әнииклопедия, red. Патриарх Московский и всея Руси Кирилл, t. XVII, Москва 2008, s. 507-508 [Б.М. Клосс, А.А. Турилов]; А.В. Назаренко, Аревнял Русь на международньхх путях. Междисииплинарные очерки культурньх, торговых, политических связей IX-XII вв., Москва 2001, s. 631-633; А.А. Мельнікаў, Еўфрасіння Полачкая (Жьиіе Еўфрасінні Полацкай з каментарыямі А. А. Мельнікава), [w:] 3 неапублікаванай спадиьлнь: Манаграфіі, артькульи, вершы, матәрыяль навуковай канферәниъиі, успаміны сучаснікаў, Мiнcк 2005, s. 14-315.

39 I. Stebelski, Dwa wielkie światła na horyzoncie połockim z cieniów zakonnych powstajace..., Lwów 1866 , s. 70 i n. 


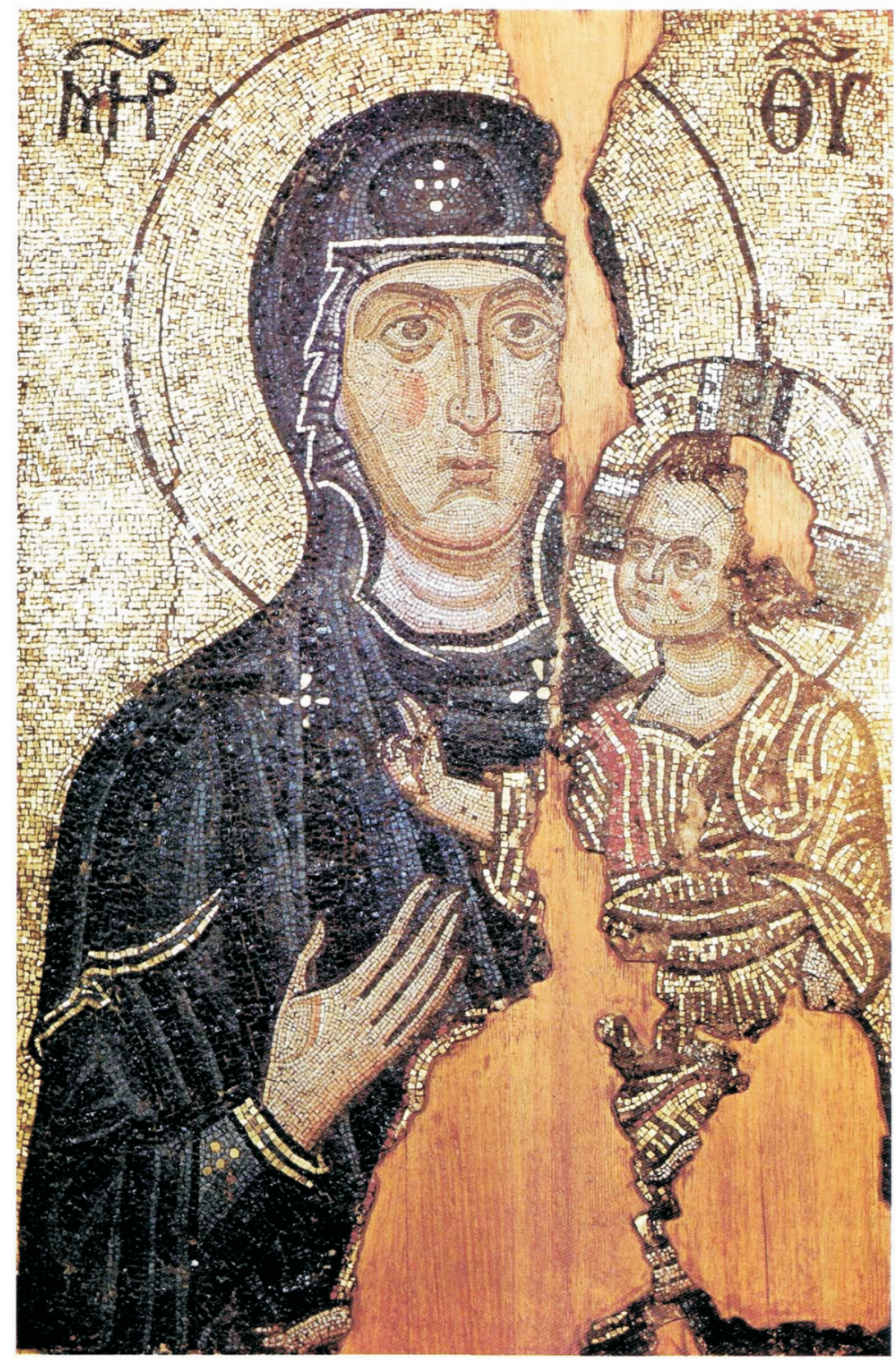

Boska Hodegetria, ikona mozaikowa, koniec XII - początek XIII w., klasztor Chilandar na Świętej Górze Athos, wymiary: $57 \mathrm{~cm} \times 38 \mathrm{~cm}$. Źródło: B.Н. Лазарев, История византийской живописи, Москва 1986, s. 97 , i1. 322. 
w Efezie. Cesarz i patryarcha zrozumiawszy jej wielką ku Bogu i przeczystej Bożej Matce miłość i uprzejmość, zezwolili na jej prośbę, i posławszy do Azyi przenieśli z Efezu do Carogrodu cudowny Bogarodzicy obraz, i przysłanemu słudze imieniem Michałowi oddawszy, odesłali do św. Eufrozyny z listami swymi" ${ }^{40}$. W dalszej części wywodu uczony bazylianin potwierdził, że obraz był kopią dzieła św. Łukasza; zastanawia się, jakie były dalsze losy zaginionego w nieznanym czasie dzieła. Być może nieznana ikona z Mielnika była jedną z kopii obrazu Hodegetrii z Efezu?

Skąd wywodziła się mielnicka ikona? Nie była dziełem lokalnym, na Podlasiu nie było wówczas ośrodków, gdzie malowano ikony. Znacznie bardziej prawdopodobne, że przybyła z któregoś z ruskich (wołyńskich?) lub bałkańskich centrów prawosławia.

Pewną wskazówką odnośnie do pochodzenia mielnickiej ikony mogą być wiadomości o świątyniach wzniesionych przez Daniela w Chełmie. Ich opisy - architektury i wyposażenia - zachowały się w cytowanym latopisie.

W 1259 r. Daniel „созда же ц[е]рк[о] вь с[вя]т[о]го Ивана красну и лепу. [...] напреди ихъ же бе изделанъ Сп[а]съ а на полоуношных с[вя]ты Иванъ якоже всимъ зряшимъ дивитися бе. украси же иконы еже принесе ис Кыева. каменьемь драгымъ. и бисеромъ златымъ. и Сп[а]са. пр[ечи]стое Б[огороди]це иже емоу сестра Федора и вда из монастыря Федора. иконы же прине. изо Ороучего. Оустретенье. о о[т]ца его. дивоу подобны яже погореша во ц[е]ркви стго Ивана" 41.

Wedle tego źródła "[Daniel] wybudował [w Chełmie] przepiękną cerkiew św. Jana. Przywiózł [do niej] z klasztoru św. Teodora z Kijowa ikony Zbawiciela i Bogurodzicy, które mu dała jego siostra Teodora, i ozdobił je drogimi kamieniami i złotym bisiorem. Przywiózł także cudne ikony z Owrucza, [które otrzymał] po swoim ojcu. Spłonęły one w cerkwi św. Jana i z tych ikon został jeden tylko Michał" 42 .

Nieco więcej informacji zachowało się na temat świątyni Bogurodzicy, która rozmiarami i pięknem nie ustępowała cerkwi św. Jana: „Въ лет[о] [6768, tj. 1260] Созда же церк[о]вь привеликоу во граде Холме

40 Tamże, s. 71.

41 Полное собрание, s. 843-845.

42 Tamże. Opis cerkwi św. Jana w Chełmie na podstawie latopisu w interpretacji Mikołaja Karamzina przytacza Julian Kołaczkowski, zob.: Przetrzaśnienie artykułu w Bibliotece Warszawskiej z miesiaca stycznia r. b., pt. Przedchrześciańskie (sic!) na ziemi naszej pomniki dla bóstw Lelum polelum i Świstum poświstum, „Biblioteka Warszawska” [1844], t. IV, s. 437-445; L. Bieńkowski, S. Pawiowa, M. Stankowa, Początki miast w dokumentach, [w:] Kalendarz Lubelski 1966, Lublin 1966, s. 62. 
во имя прес[вя]тыя приснодвъ1я М[а]рия величествомъ красотою не мене соушихъ древни[х]. и украси ю пречюднами иконами принесе же чашю о земля Угорьскыя. мрамора багряна изваяноу моудростью чюдноу. и змьевъ главы беша окроугъ ея. и постави ю пре дверми ц[е]рк [о]вьнымъ1 нарецаемыми ц[а]р[с]кыми створи же в неи крестилницю кр[ес]тити водоу. на с[вя]тое Бо[го]явление створи" 43.

Bogato zdobione szlachetnymi kamieniami i perłami ikony do chełmskich cerkwi zostały przywiezione z kijowskiego klasztoru św. Teodora Studyty oraz z Owrucza ${ }^{44}$. Być może stamtąd wywodziła się też ikona z mielnickiej cerkwi Bogurodzicy?

We władaniu wołyńskiego księcia znajdował się przez pewien czas Drohiczyn ${ }^{45}$, miejscowa cerkiew Bogurodzicy także miała być fundacją Daniela, lecz nie zachowały się żadne świadectwa o jej ówczesnym wyposażeniu.

Włodzimierz Wasilkowicz, syn i następca Wasilka, brata Daniela, do cerkwi w Bielsku w 1288 r. ofiarował księgi i ikony: „Тако же и в Бельске поустрои церковь иконами и книгами" 46 . Nic nie wiadomo o owym darze, lecz z informacji tej można wysnuć wniosek, że w średniowieczu ikony docierały na te ziemie $\mathrm{z}$ południa, być może $\mathrm{z}$ Wołynia.

Przy aktualnym stanie badań nie uda się odnaleźć odpowiedzi na pytanie, przed jaką ikoną modlił się w 1260 r. książęcy brat Wasilko. Obecnie jest to jedyny i najstarszy zachowany ślad istnienia otoczonych kultem ikon na Podlasiu. Nie wiemy również, skąd ta ikona się wywodziła, jednakże fakt, iż jeśli nie najstarsze, to jedne z najstarszych cerkwi na Podlasiu: w Drohiczynie, Bielsku i Mielniku, zostały wzniesione i wyposażone przez władców wołyńskich, Daniela i Włodzimierza Wasilkowicza, świadczy o kierunku, z którego docierały na Podlasie także przedmioty kultu i ikony. Wszystkie zostały najpewniej doszczętnie zniszczone wraz z cerkwiami podczas najazdów tatarskich w XIII-XIV w. ${ }^{47}$

43 Полное собрание, s. 845-846.

44 J.T. Stecki, Wołyń pod względem statystycznym, historycznym i archeologicznym, b.m.w., 1864, s. 276; M. Czajkowski, Owruczanin, Pisma, t. IV, Lipsk 1863, s. 52.

45 Городския поселения, t. II, s. 85-87.

46 Полное собрание, s. 925; Карамзин, История государства российскаго, s. 112. Informacjе̨ powtarza wielu historyków: П. Бобровский, Материальь для географии и статистики России, Гродненская губерния, t. II, С. Петербург 1863, s. 904.

47 P. Krasny, Architektura cerkiewna na ziemiach ruskich Rzeczypospolitej 1596-1914, Kraków 2003, s. 30. 
Abstract

The unknown icon in Mielnik. The beginning of icons in the Podlasie Province

The Hypatian Codex (also known as Ipatiev Chronicle) contains the oldest information about the icons on the Podlasie region. At the end of 1260, it was realized that prince Daniel's brother, Vasilko, prayed to God in front of the icon of Holy Mother of God of the Orthodox Church in Mielnik. It is not known what was on the icon. There are not any evidences of existing Jezus Christ's icon, so Vasilko probably prayed to the Saviour through the famous icon known for its miracles in the Orthodox Church in Mielnik. Two Russian authors of the 19th century, Fiodor Pokrowski and bishop Josif mention the icon that was placed in the altar of the Orthodox Church in Mielnik. However, it is extremely doubtful whether the medieval icon was preserved in the provincial Orthodox Church and there is no information about the icon in 19th century while the Orthodox Church was controlled. The article is an attempt to explain doubtful interpretations of the non-existent icons.

Key words: Podlachia, icons, Mielnik, icon famous for miracles, Vasilko

Резюме

\section{Неизвестная икона из Мельника. Вклад в историю икон на Подляшье}

Старейшее воспоминание об иконах на Подляшье содержит Ипатьевская летопись. В 1260 году летописец отметил, что брат князя Аанила, Василько, молился к «Спасителю Избавителю» перед окруженной культом иконой в церкви Богородицы в Мельнике. Неизвестно, как выглядела икона. Поскольку нет прямых доказательств существования чудотворной иконы Христа, Василько, наверное, молился к Избавителю через неизвестную сегодня чудотворную икону в церкви Богородицы в Мельнике. Об иконе вспоминают два русских автора девятнадцатого века, 
Федор Покровский и епископ Иосиф, которые считали, что икона в конце XIX века находилась на алтаре церкви в Мельнике. Однако очень сомнительным является то, что до того времени в провинциальной церкви сбереглась средневековая икона. Нет информации о ней во время посешения в восемнадцатом веке церкви в Мельнике. Статься является попыткой объяснения сомнительных интерпретаций относительно несуществующей иконы.

Ключевые слова: Подляшье, иконы, Мельник, чудотворная икона, Василько 